\title{
Cecilia Razovsky, the American Activist Who Rescued German Jewish Children (1933-1945)*
}

\author{
Bat-Ami Zucker, Bar-Ilan University, Ramat Gan, Israel
}

\begin{abstract}
This article deals with the reaction of one particular American Jewish sector - the Jewish women - and their response to Nazi persecution of European Jews in the 1930s and the 1940s. As against the widespread accusations that American Jews did not do enough to help their co-religionists during those tragic years, ${ }^{1}$ this paper claims that Jewish women, of all social standing - from homemakers to professionals - were actively involved in organizing rescue operations and assisting refugees. Of particular note is one extraordinary woman - Cecilia Razovsky-Davidson.
\end{abstract}

In 1933, approximately 520,000 Jews, including 117,000 children and youth between the age of six and twenty-five, lived in Germany. During the first months of the Nazi regime, the majority of them cherished hopes that Hitler would not rule for long. In February and March 1933 only the political opponents of the Nazi regime left Germany in haste.

This complacency within the Jewish community was rattled on April 1, 1933 by the government-ordered one-day boycott of Jewish businesses. The one-day boycott followed a series of anti-Jewish laws, primarily professional bans, which caused many Jews to panic and to flee the county. More than 50,000 Jews left in the first months of the Nazi dictatorship. After the first wave, emigration of Jews proceeded in response to the currents of anti-Jewish policy. The November 1938 pogrom- Kristallnacht - ("The night of the broken glasses") indicated, even for those who were hesitant and preferred to wait, that there was no longer any future for the Jewish community in Germany. Altogether, from 1933 until emigration was banned in October 1941, approximately 350,000 Jews, who could, fled Germany. The brutal persecution of German Jews which gradually intensified called for an emergency solution. The problem was that European countries were closing their doors. The United States, because of its humanitarian traditions, its history of granting asylum to the needy, and its rhetoric of freedom and democracy, became the most sought-after haven for German Jews. However, events in Germany coincided with wide-spread anti-immigration sentiments creating a xenophobic climate coupled with the worst economic depression that the United States

Women in Judaism: A Multidisciplinary e-Journal Volume 17 Number 2 (2020) 
ever faced. These two factors soon manifested themselves in virulent anti-Jewish attitudes that were reflected negatively on the attempts to assist Jewish refugees desperately seeking shelter.

Already in September 1933, German Jewish relief organizations founded the Central Organization of Jews in Germany, which recognized that something had to be done at least for the children. ${ }^{2}$ Its goal was to help children between the ages of 10 and 16 emigrate by coordinating with foreign Jewish organizations willing to help. The Central Organization had a working relationship with a local office in each country. In the United States the main contact was with the Refugee Committee, run by Cecilia Razovsky.

This article deals with the reaction of one particular American Jewish sector - the Jewish women - and their response to Nazi persecution of European Jews in the 1930s and the 1940s. As against the widespread accusations that American Jews did not do enough to help their co-religionists during those tragic year, ${ }^{3}$ I wish to claim that Jewish women, of all social standing - from homemakers to professionals - were actively involved in organizing rescue operations and assisting refugees.

The focus here is on one extraordinary woman - Cecilia Razovsky-Davidson.

Born in St. Louis, Missouri in 1887 to a poor immigrant family, Miss Razovsky, as she was called, was a social worker by profession who literally dedicated her life to the cause of Jewish refugees. Active in all major Jewish and non-Jewish American immigration and rescue organizations for more than fifty years, she was an acknowledged authority on immigration, refugees, Jewish refugee children and displaced persons. As the Executive Director of the National Coordinating Committee for Aid to Refugees and Emigrants Coming from Germany (NCC), the German-Jewish Children 's Aid (GJCA), and the Head of Migration Department of the National Refugee Service (NRS) -among other organizations, Razovsky was highly efficient in helping refugees get the necessary visas, affidavits, and information needed for their entrance into the United States. After their arrival, she helped the refugees to find relatives in the US and to locate jobs and cities for permanent settlement.

Women in Judaism: A Multidisciplinary e-Journal Volume 17 Number 2 (2020) ISSN 1209-9392 
Among her so many activities, I wish in this paper to concentrate on her program that brought over 1000 Jewish refugee children to the US, and placing them with Jewish foster families. She created and administrated a network in over one hundred cities all around the country with the aid of professional and unprofessional women that she recruited, all working long hours for what she considered "a sacred mission" - the rescue of refugees and especially children from Hell.

It all began on 20 August 1933, when the Executive Committee of the American Jewish Congress voted in a resolution to organized a movement to bring children from Germany for adoption by American Jewish families ${ }^{4}$. The idea was to arrange for affluent American Jewish families to willingly agree to adopt German Jewish children, who suffered from the mental, physical and moral terror to which they were exposed in Nazi Germany. The American Jewish Congress and the Joint Council on Immigration, together with representatives of other Jewish groups, believed that such an arrangement should be in full compliance with immigration laws and, therefore, have a better chance of being approved by the administration and accepted by the American public. Moreover, sufficient evidence would be produced by the Jewish organizations to make sure that these children would not become public charges, and the adoption would be carried through good faith.

Hyman Bloomfield ${ }^{5}$ was asked by the Executive Committee to meet with the Secretary of State to obtain the State Department's consent to instruct its consuls in Germany to exercise leniency in expediting the humanitarian migration of these minors. However, the answer he got was that since the quota for Germany was "under-issue there would be no problem with regard to children "as well as to adult visa applicants." In other words, no special preference was approved for German Jewish children. ${ }^{6}$ Against the original offer by the American Jewish Congress with regard to adoption of children, it was unanimously agreed that the adoption plan was both unwise, and inhuman. There was in addition a legal problem. According to US Adoption Laws, no child may be legally adopted unless he/she is present in court at the time the adoption takes place. Since the children in question were still in Germany, any potential adoption was irrelevant. ${ }^{7}$ However, at a meeting of the Board of Directors, GJAC, in December 1935 , 
the question of adoption was raised again. Razovsky reported that a few families asked to adopt children at present in Germany. Given the situation in Germany, it was agreed that a letter would be written to Dr. $\mathrm{Kahn}^{8}$ to inquire whether there were children in Germany whose parents would be willing to offer them over for legal adoption in the US. The Board decided to apply to the State Department for permission to bring additional children for adoption. ${ }^{9}$ At the same time Razovsky reported to Kate Rosenheim ${ }^{10}$ of the Central Organization in Berlin on 6 January 1936, that "the only way in which we can arrange for adoptions will be to find out which of the children who have been sent to the United States, are available for adoption. ${ }^{11}$

Concerning the difficulties in advancing the adoption plan, it was therefore suggested that it would be preferable to consider bringing to the US children whose parents agreed to send them to America until the situation in Germany improved. Dr. B. Kahn-then European representative of the Joint Distribution Committee -- proposed to start with 250 children, as a test case. ${ }^{12}$ He reported that a questionnaire asking for comprehensive data on the children's health, social background and other details, had already been sent to the Central Organization in Berlin. In a meeting in New York on 18 April, 1934, it was decided to form a new organization, the German-Jewish Children's Aid, Inc., (GJAC) with Dr. Solomon Lowenstein, Chairman, and Cecilia Razovsky, Executive Director.

The work was divided between the Kinderauswanderung Department in Berlin and the GJAC's office in New York. The German organization received requests for assistance from Jewish communities or parents applying directly to the Central Organization. The department considered each case and then contacted the appropriate central Jewish committees in New York. The workers in Germany distributed questionnaires to the individual offices which were to be sent back with details about the children, their photos and health certificates. Herta Souhami ${ }^{13}$, a social worker, worked for the Kinderauswanderung department in Berlin. Her particular responsibility was to check the applications of the children before they were approved to be sent to the office in New York. The department chose the children, or rather they recommended them, though the final decision lay with the office in New York.

Women in Judaism: A Multidisciplinary e-Journal Volume 17 Number 2 (2020) 
Most of the children left from Berlin or Frankfurt am Main. The parents brought the children that were collected by the department's representatives, who made sure they have submitted all the necessary documents. Then the children were brought to the train, to start the long trip to the US.

Two stories, told after more than fifty years, reflect best how the children felt during the process - from family home in Germany to foster home in the United States:

On January 28, 1935, 13-year-old Erich Oppenheim stood before the congregation of his synagogue in the German town of Nentershausen on the day of his bar mitzvah and for the first time publicly read from the Torah. The next day, he and a younger brother boarded a ship to America to escape Nazi persecution, never to see his parents and two other brothers again. He explains, some fifty years later, that "our father settled us in our cabin, blessed us for the last time and left. I recall feeling sort of numb and lost."14 Werner Michel was a sweet-faced boy of 12, small for his age and quite. His mother rode with him on the train to Mannheim. The day was bitterly cold, and she made certain he wore his dark, heavy overcoat and wool cap. She sat close and held his hand, encouraging him, promising they would soon meet in America. At the station in Mannheim, his mother broke down. He told her not to cry. He boarded the train to Hamburg and found a seat by the window, following her as long as he could. Then he was alone. He was deposited in St. Louis with a tag on him, like a piece of baggage. He recalls that he "was frightened, unhappy and terribly lonely."15

Each group consisted of approximately 15 to 20 children and was accompanied by volunteers or by employees of the department, who were responsible to bring them safe to the U. S. ${ }^{16}$ About one thousand Jewish children were smuggled clandestinely out of Europe -mainly from Germany and Austria between 1934 and 1945 and taken to live with Jewish foster families in America. Although their stories vary, most of the children found themselves in warm and supportive homes and took very well to their new families. Some children, however, were subject to miserable experiences, when their foster-parents forced them to act as the family's servants and chambermaids. Foster families were supposed to nurture the children, and ease their transition into American life while helping to erase painful memories of discrimination and persecution. They

Women in Judaism: A Multidisciplinary e-Journal Volume 17 Number 2 (2020) ISSN 1209-9392 
were supposed to support them when they missed their parents. The reality, though, was different. The story of W.'s reflects one such case.

Foster care was the most miserable period of my life. No one understood me. My foster parents lived in their little dream world and thought that by giving Me a home they had done their bit for the struggle against Hitler. Once I Arrived, they hardly paid any attention to me, leaving all my problems To the local caseworker in charge of me. ${ }^{17}$

On the other hand, most children though remembering the agony, the pain, the longing for parents and the emptiness they underwent, at the same time felt appreciation for the foster parents and their new friends.

A prayer written for New Year's Eve, 1943 by Hans J., one of the refugee children, reflects their complicated condition:

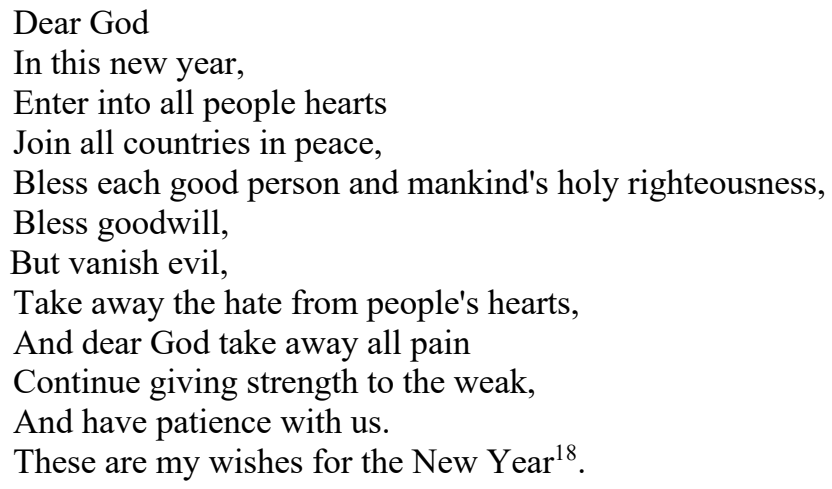

Iris Posner, who undertook the mission of bringing their stories to the public eye and giving their rescuers the credit, they deserved, concludes that "these children were able to lead their lives in safety, to raise families of their own, and to achieve success and even fame." 19

Given the general anti-immigration climate and particularly the strict and uncompromising attitude of the Department of State and the US consuls, who were consistently and systematically employing various means to deny immigration visas, ${ }^{20}$ Jewish leaders decided to seek assistance from the secretary of labor, with whom Razovsky had personal relations, and who appeared more sympathetic to Jewish misery. ${ }^{21}$ Already in late 1933, it was agreed that the rescue of German Jewish children should be the first priority. Jewish leaders made use of an overlooked provision of the

Women in Judaism: A Multidisciplinary e-Journal Volume 17 Number 2 (2020) 
Immigration Act 1917, the legality of which was later confirmed by the attorney General. $^{22}$ This provision enabled the Secretary of Labor, Frances Perkins, to authorize the entrance of unaccompanied children under the age of sixteen. Since the Secretary of Labor also had the statutory right to accept bonds for unaccompanied children, the attorney general's decision opened a promising avenue for bringing the children to the US, without invoking the public charge clause.

A new organization, the German-Jewish Children's Aid, Inc., (GJCA) which Razovsky was instrumental in establishing and becoming its executive director, was put in charge of bringing Jewish children into the United States. In order to guarantee that the children would not become a public charge, the GJCA opened a bank account of $\$ 27,000$. Perkins did indeed agree later that year to bring over 250 unaccompanied Jewish children from Germany, as the first stage of the plan. The first ten children arrived in New York on 9 November 1934 and were greeted at the port by Razovsky. ${ }^{23}$ No doubt, the program operated smoothly thanks mostly to the Secretary of Labor and Cecilia Razovsky. Among other Jewish and non-Jewish refugee organizations, the GJAC was the first Jewish refugee organization in the United States created exclusively for the purpose of transferring Jewish refugee children from Nazi Germany to the United States and caring for them after arrival. ${ }^{24}$

Razovsky operated simultaneously on two fronts. She established contact with the Hilfservein der Deutchen Juden - the Berlin based Jewish organization that was in charge of locating and choosing the children, as well as delivering the relevant documents to the main office in New York. ${ }^{25}$ At the same time, Razovsky made all the necessary arrangements to receive the children in the US. This entailed locating proper foster homes, making provisions for the children's maintenance after arrival, and training qualified social workers to handle the special problems of the children who were separated from their families.

As the children's files indicate, Razovsky's concern for them was far beyond the call of duty. She extended personal attention to each child, seeing to his medical and behavioral problems as well as to lesser ones. One sixteen-year-old boy developed schizophrenia two years after his arrival. Razovsky not only immediately hospitalized

Women in Judaism: A Multidisciplinary e-Journal Volume 17 Number 2 (2020) ISSN 1209-9392 
him in a New York sanitarium, but, was also there on frequent visits to provide support during his dark moments. Or the case of an eleven-year-old boy, ${ }^{26}$ who desperately longed for his mother, "literally driving [his foster parents] crazy with his weeping and wailing to be sent home to his 'mommy." Razovsky personally visited the boy, brought him to New York where she could closely watch him, and found for him a therapist, who reported to her personally. There were also cases of children who had troubles at school, some were lonely, and had difficulties integrating into the new surroundings. As Michael Werner confessed sixty years after his arrival into the US: "I belong nowhere."27

Notwithstanding the existence of certain problems, most of the children adjusted well and were happy with their foster families. In 1941, Razovsky reported to the GJAC Board of Directors: "They live happy, normal life in 103 American communities. Several of the children have reached the age of 21 and are Naturalized American citizens. Many of them are already self-supporting and a few others are contributing toward their own support. Nine have married and 105 are united with their own families."28

During the period 1934-1943, the GJAC under Razovsky management, brought over one thousand unaccompanied children, ranging in age from two to sixteen. This task was made all the more complicated by the fact that it was carried out as a clandestine operation, "without any form of publicity in the newspapers or any other public method of advertising (underlined in the origin") ${ }^{29}$ most likely out of fear that anti-Semitic organizations that ${ }^{30}$ warned against "a flood of Jews to America," would interfere. However, in case it gets to the public, Jewish leaders believed that children-at-risk would arouse less antagonism, perhaps even some sympathy. Since they would not compete with other Americas for jobs, they might gain admission more readily.

Moreover, to ensure the government that the children would not become public charges, a special guarantee fund was established and an arrangement was made with Jewish foundations to keep these funds on deposit as long as it was required by the government. Transportation costs were met by contributions from individuals in accordance with the immigration law that prohibited payment for transportation by organization. ${ }^{31}$

Women in Judaism: A Multidisciplinary e-Journal Volume 17 Number 2 (2020) 
Although everyone involved tried to work discreetly, news of the children's arrival became public and soon the American Coalition of Patriots, Civil and Fraternal Societies was attacking the Department of Labor for its cooperation in the "systematic importation of indigent alien children." ${ }^{32}$

Cooperation between the GJAC in New York and the Hilfservein der Juden in Deutschland in Berlin did not always operate as smoothly as expected. Many misunderstandings during the first years were due to the language barrier and the discrepancies between the German parents' high expectations and the more prosaic realities, which caused frequent complaints from families. Razovsky was upset that "these boys that find our food very disagreeable nevertheless eat with hearty appetite and gain considerable weight." ${ }^{33}$ In a report to the Board in May 1935, Razovsky stated: "It is very difficult for European to understand that 'Uncle Sam' is no longer the rich uncle and therefore cannot be as generous now as he has been in the past." 34 Thus, during the first two years of operation, the GJAC found itself facing opposition on several fronts. Jewish social workers in Germany were still not attuned to the largescale project of selecting the children and the management of the many requirements. In addition, the program that would separate children from their families attracted protest from several German Jewish bodies. In the US, the resources needed for the maintenance of each child were difficult to collect. And to cap it all, even with the meager number of children signed up for the project, there were not enough free fosterfamilies to take in the children. However, with good will on both sides, by 1941 these misunderstandings were eventually resolved and cooperation went on amicably, solving together grave problems and in the process developing close and friendly relationships. ${ }^{35}$ By the close of the 1937 fiscal year, 250 children had been brought in and a request was made to the government to agree to the admission of a further 120 , at the rate of ten children per month, for the fiscal year 1938. By March first, 1938 GJSC had 351 children under its auspices and its directors contemplated terminating the program. It should however be noted that on 7 December 1937, the Board of Directors of the NCC had recommended the continuation of the work of GJAC. ${ }^{36}$ 
By now there was an improvement both in Germany and the United States. The German office had gained more understanding with the procedure and in the US, there was a growing awareness to the situation in Germany and therefore a growing tendency by American Jewish families to accept refugee children. After the first three years, during which the children were sent directly to foster parents, they were now having a few days for recovery and orientation, which enabled them better conditions to acclimatize to life in American. The change enabled psychologists and social workers to observe the children in a more friendly environment and look for special problem, what helped to place the children in suitable homes. ${ }^{37}$

It should be noted that unlike in Great Britain, where the Kindertransport was backed by the government, children rescued through the United States were brought privately and under strict immigrations laws. The 'mission' was accomplished in the face of powerful economic, social, political, religious and governmental constraints. Moreover, Great Britain's efforts spanned two years whereas in the US the effort spanned more than a decade, from 1934 to 1945. In that time Jewish organizations and others, such as Quakers and Unitarians, raised money to ship over unaccompanied Jewish children from Europe to the United States, ranging from 14 months to 16 years old. When evaluating the program, it is clear that GJAC and in particular Cecilia Razovsky's achievements present a grand rescue operation.

Razovsky's efforts on behalf of refugees did not end after the war. She traveled to concentration camps in Germany and Austria to find surviving children and accompany them to temporary safe places, from which they were later sent to Palestine and the United States. As director of immigration operation in Germany and Austria, on behalf of UNRRA, Razovsky assisted in implementing President's Truman's directive of 22 December 1945, which authorized the admission to the United States of displaced persons living in the American zones in Germany and Austria. Her work took her to every single displaced persons' camp and enabled her to obtain first-hand knowledge of the abilities and skills of the people waiting to be resettled. ${ }^{38}$ But perhaps her most important project at that time consistent of preparing the Central File and Card Index of Displaced Persons. This record was invaluable to the many displaced persons who 
were trying anxiously to find surviving relatives. She recalled one such incident as follows:
A little boy about ten years old had been in a concentration camp And did not know where his father was or whether he was alive. We included the child's name in our cable to Palestine and received A cable from his father in Palestine saying how happy he was to learn his child was alive.
When we told the boy the news he gasped: 'you have heard from my father... My father is alive'... trembling from head to foot he took the cablegram and Showed it to the other children, ${ }^{39}$

Her books, articles and speeches on immigration, refugees and children were well known among the thousands she rescued and the many organizations in which she was active. She was praised as a person of 'competence and spirit' and played a major role in the rescue of Jewish refugees. ${ }^{40}$

Given Razovsky successful operations during the period between 1933 and 1945, one wonders how she accomplished what her male Jewish counterparts were less successful in achieving. The main reason was probably Razovsky's keen intelligence and strongwilled personality, the fact that she never took 'no' for an answer; and her ability to focus her experience on the issue ahead. Razovsky's absolute devotion to the rescue of refugees and especially Jewish refugee children went back to her youth. Growing up as she did in a poor immigrant neighborhood, she obtained first-hand knowledge of the immigrants' problems. Moreover, the fact that she spoke several European languages including Yiddish - enabled her to converse freely with the immigrants. Having developed a sense of solidarity with the immigrants' misery and aspirations, it was quite natural for her to pursue a career as a social worker. Her activities were motivated above all by her very human compassion, which is so evident in her personal relations with the refugees or their relatives and in her heartfelt applications to the US administration, when she always emphasized the immorality and injustice of the Nazi regime. Nor was she loath to urge government officials to live up to America's traditional commitment to provide a 'haven for the oppressed.'

She adopted a grass-roots approach to her work, recruiting house-wives, delivering speeches all around the country, creating volunteer centers and never allowing high 
politics to sway her from her cause. With much dedication and resolution, Razovsky set up an active national network of Jewish women based on the Jewish tradition of communal solidarity. Razovsky and these anonymous Jewish women charted the course, laid the groundwork, and institutionalized what turned to be a major undertaking. In the long run, their deeds bore an ideological and moral message for their own community and society as a whole.

No doubt her single-minded focus on one objective - the rescue of Jewish refugeeswas a major contributor to her success. High politics was never on her agenda. Even the emergence of antisemitism in the US and the anti-immigrant climate in Congress did not deter her from her enterprise. Unlike other American Jewish leaders, who were hindered by such considerations when attending to rescue issues, Razovsky refused to succumb to political interest and pressures. The fear that Jewish efforts to bring Jewish refugees into the country in the midst of the depression could cause antisemitism and thereby jeopardize their well-being resulted in cautious behavior, which, in contrast to Razovsky, proved insufficient. ${ }^{41}$ Her outstanding devotion to assisting refugee and refugee children, reveal her as a woman who dedicated her personal life to the Jewish people. She possessed integrity, assertiveness, a strong will and the courage to face higher authority in what she believed was a just moral cause, even if it meant taking an unpopular stand. She demonstrates the independent moral conscience at work in human behavior and provides a point of reference in our moral discourse. Without doubt, she stands as a representative for the thousands of anonymous American Jewish women, who made a difference.

Until her death at the age of 81, on 27 September 1968, Cecilia Razovsky remained active in Jewish community affairs, tireless working for Jewish relief organizations. In a poignant obituary, Ralph Segalman from Austin, Texas wrote:

"Cecilia Razovsky...was one of the last disappearing breed."

\section{Notes}

*This article is a revised chapter from Bat-Ami Zucker's book: Cecilia Razovsky and the American-Jewish Women's Rescue Operations in the Second World War (2008).

Women in Judaism: A Multidisciplinary e-Journal Volume 17 Number 2 (2020) ISSN 1209-9392 
${ }^{1}$ Gulie Ne'eman Arad, America, Its Jews, and the Rise of Nazism, Bloomington, 2000.

2 For this reason, the Central Organization established in December 1933, the Kinderauswanderung Department. The Kinderauswanderung office was closed during the November pogrom but it did not stop its activities, now mostly in private apartments until it was officially reopened a short time later.

${ }^{3}$ Gulie Ne'eman Arad, America, Its Jews, and the Rise of Nazism, Bloomington, 2000.

${ }^{4}$ Herold Fields, Chairman, Committee on Migration, American Jewish Congress to Mr. Meyer Bloomfield, 20 August 1933, GJAC Collection, Folder 3. Yivo Archives, New York.

5 Mr. Bloomfield was a personal friend of Acting Secretary of State Phillips. Harold Field to Bloomfield 13 September 1933, GJCA Collection, folder 1. Yivo Archives, New York.

${ }^{6}$ William Carr to Bloomfield, 2 September 1933. Ibid.

${ }^{7}$ Razovsky, Executive Director, GJAC to Zentrale fuer jued, Pflegestellen u. Adoptionverjittoung, 6 January 1936, GJAC collection, Folder 64, Yivo Archives New York.

${ }^{8} \mathrm{Dr}$. Kahn was the liaison between American organizations and leasers and social workers among the Jews in Germany.

${ }^{9}$ Minutes, Meeting of the Board of Directors, GJAC, 17 December 1935, GJAC Collection, Folder 22, Yivo Archives, New York.

${ }^{10}$ Dr. Rosenheim was the director of the Kinderauswanderung department from 1934 to December 1940. From time to time, as part of her work, she accompanied the children to make sure that the children were well cared for. She always returned to Germany, as not to endanger the work of the mission in any way. In December 1940, she eventually fled with her mother to the United States. She died in San Francisco in 1980, at the age of 88. About her work, see. Kate Rosenheim, "Die Abteilong Kinderauswanderung" in Judishches Nachrichtenblatt, July 14, 1939.

${ }^{11}$ GJAC Collection, Folder 64. Yivo Archives New York. The records indicate that the question of adoption was raised several times from 1937 to 1941, but there seems to be no correspondence regarding actual adoption of children.

${ }^{12}$ Razovsky and Lowenstein, "Interview with Mrs. Stephen S. Wise," Women's Division, American Jewish Congress, 2 February 1934, GJAC Collection, Folder 3. Yivo Archives New York.

${ }^{13}$ Herta Souhami, "An interview with Ms. R. Bannit" on March 2, 1967, Institute of Contemporary Jewry, Jerusalem, ICJ/J, Souhami 1967, page [blank]

${ }^{14}$ See, John Rivera, "Jewish Children Shipped to Safety," Baltimore Sun, April 20, 2001.

${ }^{15}$ See, Susan Levine, "Beyond Hitler's Reach," Washington Post, January 5, 2003, p. W12.

${ }^{16}$ For an excellent research on the Central Organization and especially on the Kinderauswanderung department see, Gudrun Maierhof, Selbst-Behauptung Im Chaos, Frauen in der Judischen Selbsthilfe 1933-1943. (Campus Verlag, Frankfurt/New York,2001)

17 Cited in Judith Tydor Baumel, Unfulfilled Promise: Rescue and Settlement of Jewish Refuge of Children in the United States (Juneau, Alaska, The Denali Press,1990), p. 89.

18 "Final Thoughts", in Don't Wave Goodbye, Jason and Posner, eds. (Praeger, Westport Connecticut, 2004) p. 272. Hans J. became a teacher and a poet.

${ }^{19}$ Among the more famous are Jack Steinberger, 1988 Nobel Prize winner; Herbert Freudenberger, psychologist, who was granted the Gold Medal Award, 1999.

${ }^{20}$ Bat-Ami Zucker, In Search of Refuge: Jews and U.S. Consuls in Nazi Germany, 1933-1941, Vallentine Mitchel, London and Portland, 2001).

${ }^{21}$ Bat-Ami Zucker, "Frances Perkins and the German-Jewish Refugees, 1933-1940, American Jewish History, 89, 1 (March 2001), pp.35-59.

22 Section 3 of the Immigration Act, 1917, U.S. code, Title 8, sec.13, Sub. M., pursuant to Sec. 21 of the same Act. For the ruling of the Attorney General see, 'Opinion of the Attorney General of the United States', 26 December 1933,"Frances Perkins: Immigration - Public Charge Bonds", National Archives 150.01/2151 1/4, Suitland Maryland.

23 Undated letter to Commissioner MacCormack from Dr. Lowenstein, Chairman of GJCA Folder 6, Correspondence 1934. GJCA Papers, Yivo Archives, N.Y.

${ }^{24}$ Until 1939 GJAC brought over children only from Germany; from 1939 until 1941 children from Austria, Czechoslovakia, and later refugee children in transit countries such as England, Holland and Belgium joined the German children on their journey to the United States.

${ }^{25}$ Correspondence between Razovsky and the organization, 1934-1936, GJCA Papers, Folder 63, 64, Yivo Archives, New York. 
${ }^{26}$ Cited in Razovsky, "Report", June 16, 1941, GJAC Papers, Folder 29, Yivo Archives New York.

${ }^{27}$ Cited in Susan Levine, "Beyond Hitler's Reach," The Washington Post, January 5, 2003, p. W12.

${ }^{28}$ Razovsky "Report", June 16, 1941. GJAC Papers, Folder 29, Yivo Archives N.Y.

${ }^{29}$ Dr. Lowenstein to Max Kohler, Committee on German Jewish Immigration Policy, April 24, 1934, GJAC, Folder 3, Yivo Archives, N.Y.

${ }^{30}$ Its spokesman, Captain John B. Trevor called for a congressional investigation for what he considered a violation of the immigration laws. He even spread rumors that the children came from Communist families. See also, GJAC Board of Directors, 'Minutes' 14 February 1935, Folder 249. Yivo Archives, New York.

${ }^{31}$ Paul Felix Warburg opened a special account, Stephen Koshland was appointed an agent for the donors. He would be responsible for perching steamship tickets for the children. See, Solomon Lowenstein to Kohler, May 2, 1934. GJAC Collection Folder 490. Yivo Archives, New York. See also, Razovsky "Report" to Colonel MacCormack, January 1935, Folder 29, Ibid.

${ }^{32}$ The coalition represented nineteen-eight organization and claimed a vast membership. Its antiimmigration propaganda was often tinged with antisemitism.

${ }^{33}$ Razovsky to Hilfservein der Deutchen Juden 19 ,December 1934. GJAC Collection, Folder 63. Yivo Archives, New York. Razovsky later changed her mind. In a meeting with foster parents she asked them to take into account the children's misery and their worries.

$\therefore$ Razovsky 'Report - 1935' 15 May 1935. GJAC Collection, Folder 10, p.10. Ibid.

${ }^{35}$ See for example, correspondence (in German) between Dr. Kate Rosenheim in Berlin and Miss Razovsky and Lotte Marcuse GJAC New York, February, Match 1935. GJAC Collection, Forder 6. Ibid.

${ }^{36}$ During the first half of 1937 , GJAC was granted permission to sponsor an additional five non=Aryan children per month. See, " Minutes', 14 May 1937, and 20 January 1938. Chamberlain Collection, Folder 14. Yivo Archives, New York. For the recommendation to continue the program see, Goldman, 'Referendum to Members of the Board.' Ibid.

${ }^{37}$ Cecilia Razovsky and Lotte Marcuse, 'Annual Report -1938. GJAC Collection, Folder 10. Yivo Archives New York.

${ }^{38}$ She was also actively associated with the Citizens Committee on Displaced Persons in the United States, functioning in the capacity of liaison representative with national organizations to secure congressional legislation for the admission of displaced Persons.

${ }^{39}$ Cited in 'Collected Notes on Lecture by Cecilia Razovsky taken by Sylvia Milred", July 1945. Razovsky Papers, Box 4, Folder: UNRRA Displaced Persons, 1944-1946, AJHS Archives, New York. ${ }^{40}$ Fred K. Hoehler, Director, Division on Displaced Persons, UNRRA, to Razovsky, 28 September 1945. Razovsky Papers, Box 4, Folder: UNRRA Specialist, Displaced Persons, 1944-1946, AJHS Archives, New York.

${ }^{41}$ See for example, Rabbi Stephen Wise letter to Prof. Otto Nathan in September 1940, with regard to Roosevelt's re-election. Stephen Wise Papers, Box 54, AJHS Archives, New York.

See also recently published, Rafael Medoff, The Jews Should Keep Quiet, Franklin D. Roosevelt, Rabbi Stephen S. Wise and the Holocaust, (The Jewish Publication society, Philadelphia, 2019.)

\section{Bibliography}

\section{Archives:}

Yivo Institute for Jewish Research, New-York

Chamberlain Collection

German Jewish Children Aid (GJAC)

\section{American Jewish Historical Society (AJHS), New-York Cecilia Razovsky Papers}

National Archives Washington DC, Suitland Maryland

Women in Judaism: A Multidisciplinary e-Journal Volume 17 Number 2 (2020) ISSN 1209-9392

(C) 2021 Women in Judaism, Inc.

All material in the journal is subject to copyright; copyright is held by the journal except where otherwise indicated. There is to be no reproduction or distribution of contents by any means without prior permission. Contents do not necessarily reflect the views of the editors. 
United States Department of State, Collection Central Decimal Files, Record Group 59

\section{Books}

Arad Ne'eman, Gulie. America, Its Jews, and the Rise of Nazism. Bloomington:

Indiana University Press, 2006.

Baumel, Judith. Unfulfilled Promises, The Rescue and Settlement of Jewish Refuge

Children in the United States. Juneau Alaska: the Denali Press, 1990.

Jason, Philip \& Iris Posner (eds.). Don't Wave Goodbye, The Children Flight from

Nazi Persecution to American Freedom. Westport, Connecticut/London: Praeger, 2004.

Maierhof, Gudrun. Selbst-Behauptung Im Chaos, Frauen in Der Judischen Selbsthilfe 1933-1943. Frankfort/New York: Campus Verlag, 2001.

Medoff, Rafael. The Jews Should Keep Silent, Franklin D. Roosevelt, Rabbi Stephen

S. Wise and the Holocaust. Philadelphia: The Jewish Publication Society 2019.

Zucker, Bat-Ami. In Search of Refuge, Jews and US Consuls in Nazi Germany 19331941. London/Portland: Vallentine Mitchell, 2001. 